\title{
REQUIRED ADDITIONAL HEATING POWER OF BUILDING DURING INTERMITTED HEATING
}

\author{
Darius Pupeikis ${ }^{1}$, Arūnas Burlingis ${ }^{2}$, Vytautas Stankevičius ${ }^{3}$ \\ ${ }^{1}$ Department of Civil Engineering and Architecture, Kaunas University of Technology, \\ Studentu g. 48, LT-51367 Kaunas, Lithuania \\ ${ }^{2,3}$ Institute of Architecture and Construction, Kaunas University of Technology, \\ Laboratory of Thermal Building Physics, Tunelio g. 60, LT-44405 Kaunas, Lithuania \\ E-mails: ${ }^{1}$ info@holdas.lt; ${ }^{2,3}$ silfiz@asi.lt \\ Received 14 Sept. 2009; accepted 25 Jan. 2010
}

\begin{abstract}
By introduction of intermittent heating of building we can reduce the thermal energy consumption for heating. But it requires the additional power of heating system. It is determined that the most effective solution for energy savings is to enlarge the heating power approximately by $50 \%$ for most of buildings. The simulation has showed that for buildings with a medium thermal inertia (time constant $\tau=144 \mathrm{~h}$ ) the expenses by employing the intermittent heating (reduced temperature period: $12 \mathrm{~h}$ on working days and $48 \mathrm{~h}$ at weekends), pays back after one year. By designing the heating system we must pay attention to thermal inertia of building. Our research showed that for various thermal inertias of building, the adequate modes of intermittent heating must be chosen.
\end{abstract}

Keywords: heating system, intermitted heating, building cooling-down, building reheating, outdoor temperature, simulation of intermittent heating, thermal energy consumption, saving of thermal energy.

\section{Introduction}

As the price of heating energy goes up, saving of it becomes very relevant. There are many ways for saving this energy (Ginevičius et al. 2008). One of it is introduction of intermittent heating, which is more and more applied in residential houses and office buildings. This publication analyses the variants of intermittent heating of office buildings, however, the principle is similar to residential houses as well.

The required amount of heating energy to raise up the body's temperature to set-point position, depends on the physical parameters of the body, power of a heat source and other factors (Juodvalkis 2008). The power of a heating system has the most significant influence to reheating process. Also heat load depends not only on envelope heat losses, but on type of heating regime too (Valančius 2008).

Another important issue is the prognosis of building's cooling-down. If heating ceases during the winter season, huge financial losses can be suffered in the heating network during the emergency works: replacing broken piping, transferring residents, etc. (Stankevičius et al. 2007). If the building's cooling-down time is prognosticated, optimal strategy of emergency works could be chosen.

Designing of building's heating systems is regulated by mandatory legal acts - technical regulation rules (STR 2.09.04:2002, STR 2.09.04:2008). The regulation rules require to use 1.1 safety factor for heating system. The additional power of the heating system using intermittent heating has to be determined by regulation rules STR 2.09.04:2008 depending on the building's thermal inertia, reheating time and temperature reducing period. These regulation rules uses not enough of thermal inertia parameters to assess the level of thermal inertia of building, only the mass of building envelope is assessed, but not the influence of partitions and furniture, etc. inside a building nor conduction and ventilation losses. According to (Valančius et al. 2008) in most of cases the intermittent heating suffers of too low installed heating power and this is the consequence of too long reheating time.

The aim of the work is to establish the coolingdown and reheating times in various cases of building thermal inertia, to optimize the phases of intermittent heating and to determine the approximate payback of installation of additional heating power for intermittent heating mode. To calculate the periods of building's cooling-down and reheating, we need to prognosticate the outdoor temperature, to calculate heat losses through building envelope and ventilation system, to assess the internal heat gains, etc.

\section{The processes of building's cooling-down and reheating}

The rate of cooling-down of a building as a body depends on many factors: by changes of outdoor temperature, building's thermal inertia, the amount of accumulated heat in the building, heat losses through building envelope, ventilation, infiltration, etc. (Zebergs et al. 2009). 
The process of reheating is influenced by the same factors, but in the opposite direction: power of the heating source, type of the heating system, internal gains, etc.

The processes of reheating and cooling-down are closely interrelated with intermittent heating, which is divided into three phases: cooling-down, setback period and reheating (Valančius et al. 2004). Prognostication of time periods of these phases allows to optimize the process of intermittent heating. If the periods of building cooling-down and reheating are known, we can calculate the set-back temperature.

\subsection{Prognostication of dynamic outdoor temperature change}

Prognostication of outdoor temperature curve was carried out according to climatology norm RSN 156-94 and temperature records in year 1961-1990. The curve is described by the fifth degree polynomial equation. The prognosis was made by imitating two cases: "average" and "extreme" outdoor temperature change.

"Average" temperature prognosis was made according to monthly average outdoor temperature values and month's average daily variation amplitudes during the heating season. Temperature values were used of geographical location of Kaunas city. It was assumed that the average monthly value is that of the middle of the month (e.g. 15 January, 14 February, 15 March) and gradually changes evenly between "average" monthly values (Fig. 1).

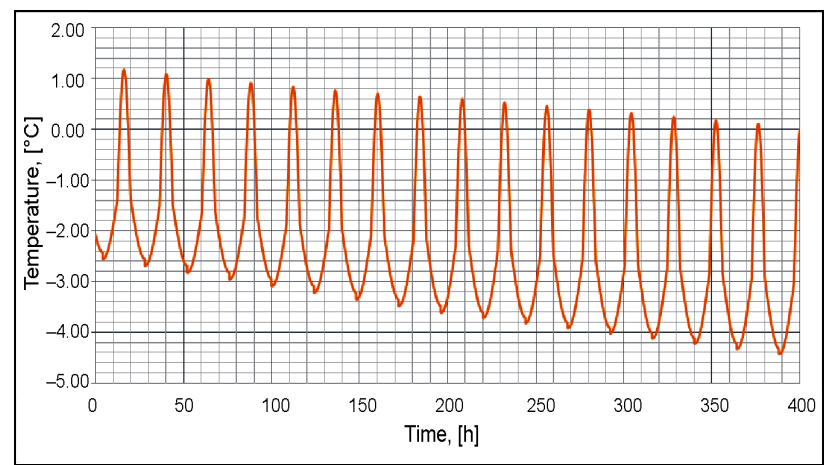

Fig. 1. "Average" outdoor temperature prognosis curve used for building simulation (period from 15th of December -1 st of January)

"Extreme" values were calculated according to five coldest days period, three coldest days and the coldest day temperature with $98 \%$ integral frequency. The temperature change during the day is prognosticated by average daily amplitude values. The principle of calculating is based on the assumption that during the period of the coldest five days, the three and one coldest days occur. After the end of the five day period, the temperature must rise and afterwards, the significant fall of temperatures of five, three and one day periods repeats (Fig. 2).

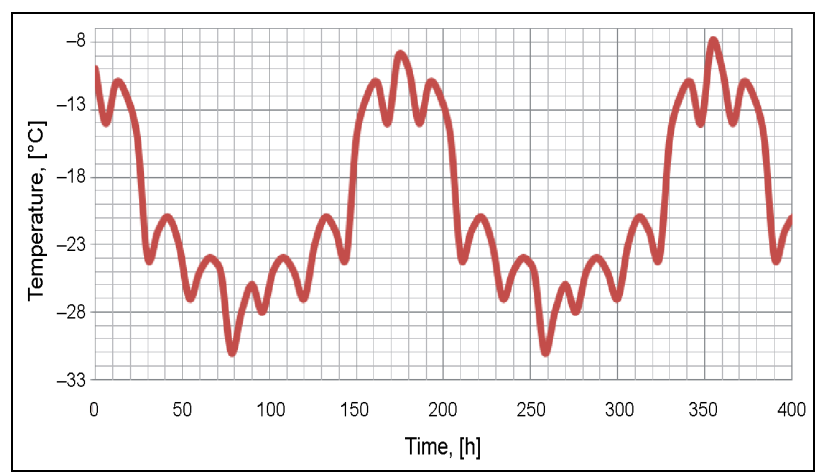

Fig. 2. "Extreme" outdoor temperature prognosis curve used for building simulation

\subsection{Modeling the processes of building cooling-down and reheating}

In order to achieve the aims of the research, an Excel calculation spreadsheet was worked out to simulate building's cooling-down and reheating. Office buildings of various values of thermal inertia $(72 \mathrm{~h}-288 \mathrm{~h})$, covering $2160 \mathrm{~m}^{2}$ of useful floor area and having different minimal normative and normative U-values (Table 1) were chosen (Šadauskienè et al. 2009). They were modeled under the "average" and "extreme" outdoor temperature change conditions during the heating season.

Table 1. Minimal normative and normative U-values used for building simulation according to STR 2.05.01:2005

\begin{tabular}{l|c|c|c}
\hline \multirow{2}{*}{$\begin{array}{c}\text { Building } \\
\text { element }\end{array}$} & \multicolumn{3}{|c}{ Office building } \\
\cline { 2 - 4 } & $\begin{array}{c}\text { Area, } \\
{\left[\mathrm{m}^{2}\right]}\end{array}$ & $\begin{array}{c}\text { Minimal normative } \\
\text { U-value } U_{M N}, \\
{\left[\mathrm{~W} / \mathrm{m}^{2} \mathrm{~K}\right]}\end{array}$ & $\begin{array}{c}\text { Normative } \\
\mathrm{U}-\text { value } U_{N}, \\
{\left[\mathrm{~W} / \mathrm{m}^{2} \mathrm{~K}\right]}\end{array}$ \\
\hline Roof & 1685 & 0.25 & 0.20 \\
\hline Ground floor & 540 & 0.40 & 0.30 \\
\hline External walls & 1980 & 0.40 & 0.25 \\
\hline $\begin{array}{l}\text { Windows and } \\
\text { doors }\end{array}$ & 342 & 1.9 & 1.6 \\
\hline
\end{tabular}

The heat losses due to infiltration and ventilation were assessed by imitating ordinary natural ventilation, i.e. the quantity of air change rate in the room is set at 0.3 times per hour (Šeduikyte et al. 2008). Internal heat gains $-4 \mathrm{~W} / \mathrm{m}^{2}$. The thermal inertia of a building as a heterogeneous body is expressed by thermal time constant $\tau$ value:

$$
\tau=\frac{C}{H},
$$

there: $C$ - active heat capacity $[\mathrm{J} / \mathrm{K}] ; H$ - heat loss coefficient of a building [W/K].

Thermal inertia - it's a measure of the responsiveness of a materials (building constructions) to variation in temperature. Materials with a high heat capacity, thermal conductivity and density display`s high thermal inertia (Corgnati et al. 2009). For calculating of active heat capacity of internal surfaces of the heated premise, the area of furniture surfaces is set at $0.5 \mathrm{~m}^{2}$ of furniture surface to $1 \mathrm{~m}^{2}$ of useful floor area of the building, and the thick- 
ness of internal active layer is calculated according to the existing methodology (Valančius 2006).

The splitting of enclosure materials into conditional layers and calculation of time step are set according to carried out research (Фокин 2006).

Cooling-down is simulated for an office building, from $22{ }^{\circ} \mathrm{C}$ to $0^{\circ} \mathrm{C}$ indoor temperature change, under the conditions of "average" and "extreme" outdoor temperature variation.

Under the conditions of "average" temperatures (see 2.1), high thermal inertia buildings cools-down more evenly than those of light thermal inertia. The turning point in change curves is found at $2{ }^{\circ} \mathrm{C}$, from where the cooling-down becomes slower (Fig. 3).

Under the conditions of "extreme" temperatures (see 2.1 ), the indoor cooling-down from $22^{\circ} \mathrm{C}$ to $0^{\circ} \mathrm{C}$ is approximately regular, however, slight variations of the curves are observed due to vast amplitudes of outdoor temperature changes (Fig. 4).

The power of the heating system has the most significant effect on the building reheating process, the value of which is determined according to the given methodology (STR 2.09.04:2008).

The reheating process is simulated for an office buildings with different values of thermal inertia in the intervals of indoor temperature from 0 to $22{ }^{\circ} \mathrm{C}$ and from 10 to $22{ }^{\circ} \mathrm{C}$, under the conditions of "average" and "extreme" outdoor temperature change curves. In order to improve the reheating of the building, additional heating power is necessary, which is added to the existing heating system during the simulation. The results are presented in Figs 5 and 6.

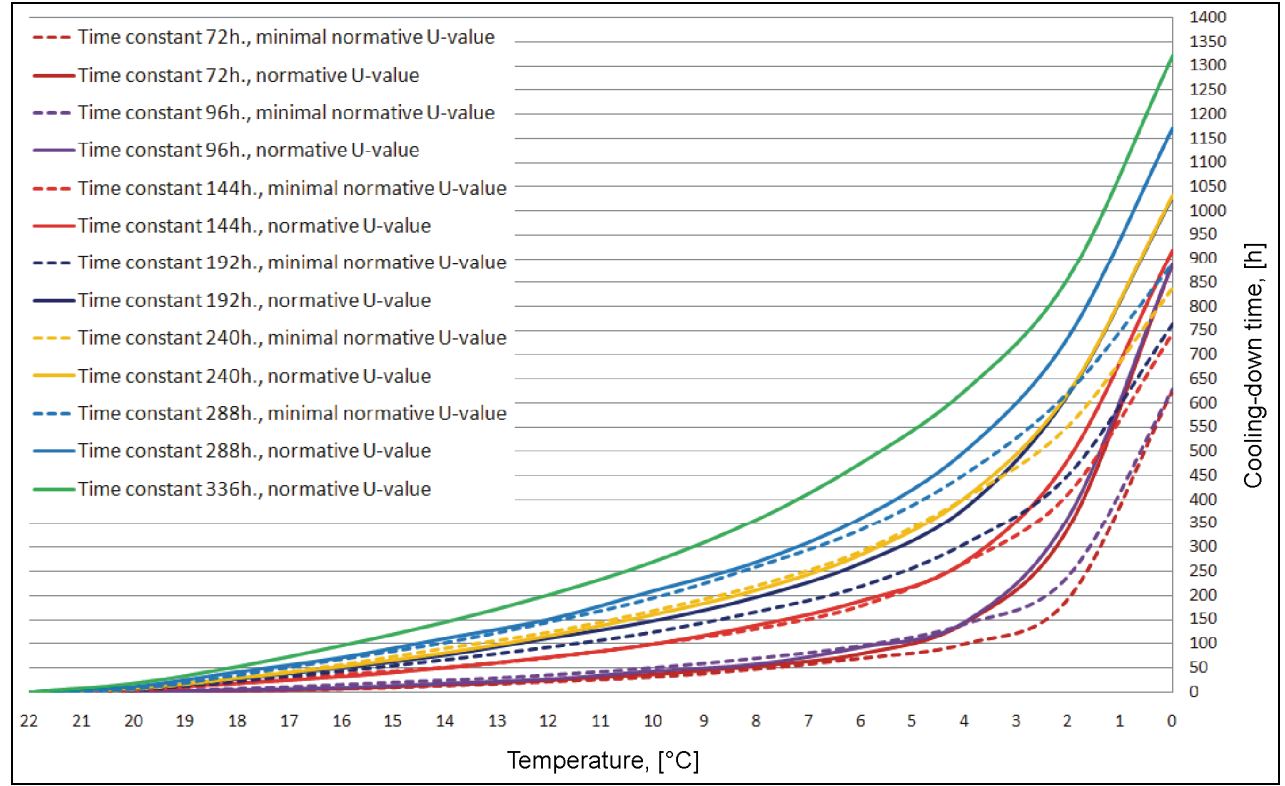

Fig. 3. Curves of building cooling-down at "average" outdoor temperature conditions

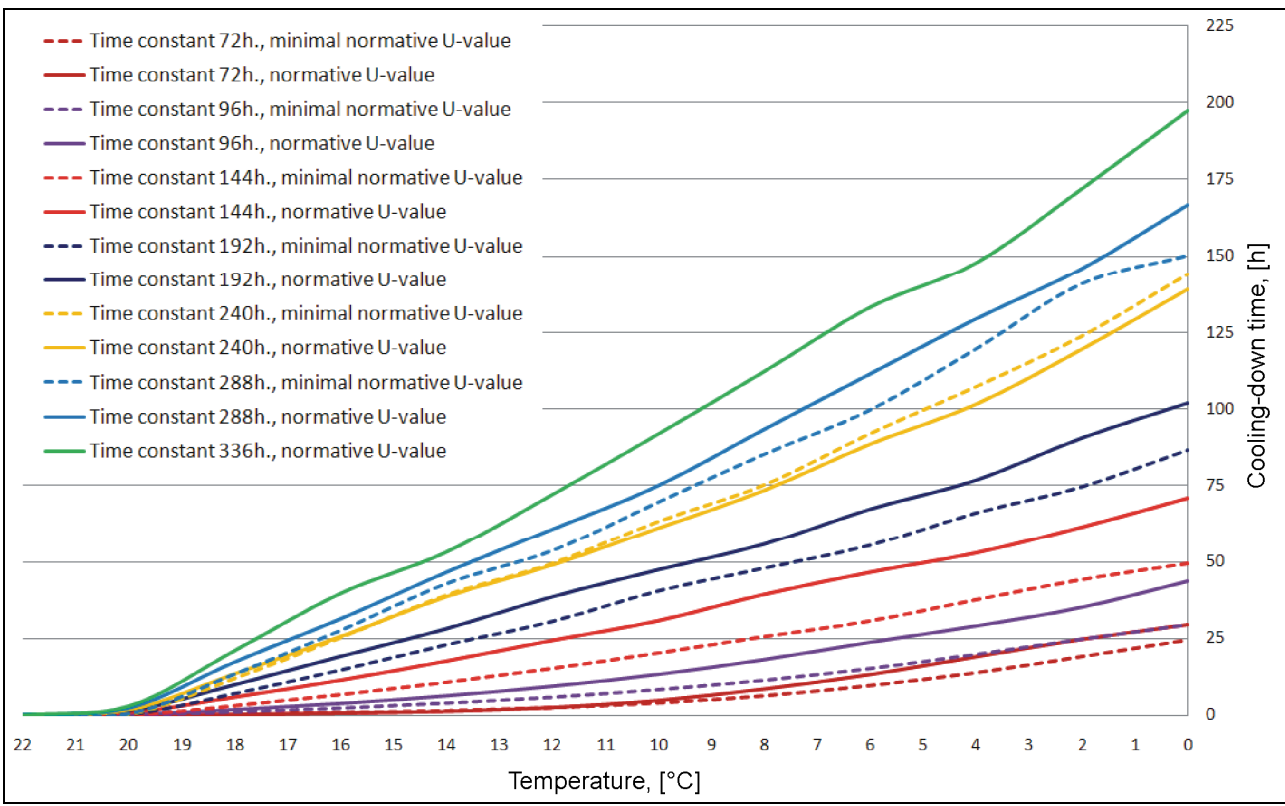

Fig. 4. Curves of building cooling-down at "extreme" outdoor temperature conditions 

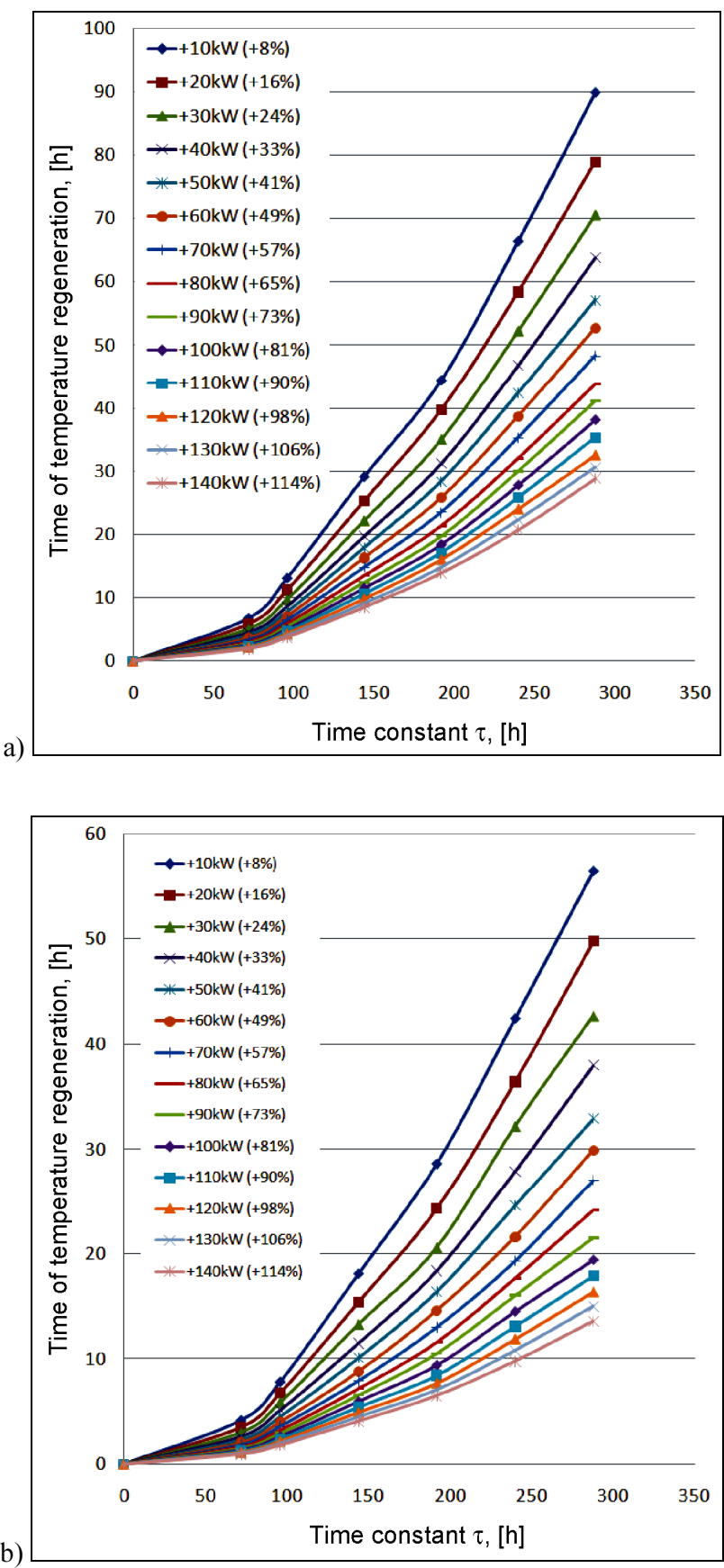

Fig. 5. The influence of additional heating power for reheating of building premises, under the "average" outdoor temperature conditions: (a) reheating from $0^{\circ} \mathrm{C}$ to $22^{\circ} \mathrm{C}$, (b) reheating from $10^{\circ} \mathrm{C}$ to $22^{\circ} \mathrm{C}$

The reheating curves indicate that under "average" outdoor temperature change conditions, additional power of heating system has more influence on the rate of heating of high thermal inertia buildings than with a light thermal inertia (Fig. 5).

Under the "extreme" outdoor temperature conditions, the curves are distributed similarly to the tendencies of "average" outdoor temperature conditions. However, slight divergences are observed due to vast temperature change amplitudes in the "extreme" temperature conditions curve (Fig. 6).
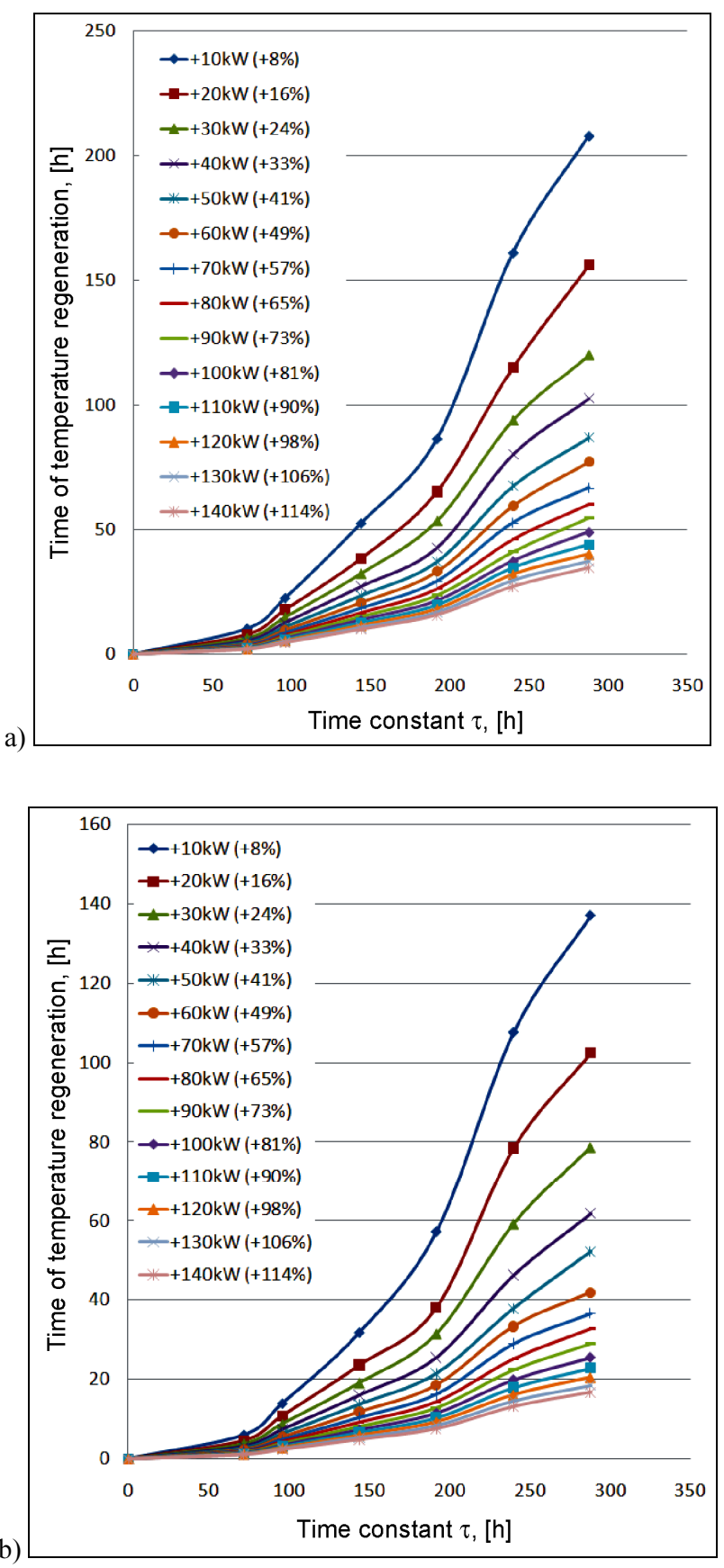

Fig. 6. The influence of additional heating power for reheating of building premises, under the "extreme" outdoor temperature conditions: (a) reheating from $0^{\circ} \mathrm{C}$ to $22^{\circ} \mathrm{C}$, (b) reheating from $10^{\circ} \mathrm{C}$ to $22^{\circ} \mathrm{C}$

\section{Required additional heating power of building dur- ing intermitted heating}

\subsection{Optimization of intermittent heating phases}

Intermittent heating of a building, also known as periodic or discontinuous heating, from the point of view of time is splitted down into three phases: cooling-down, setback period and reheating. The cooling-down phase depends on building's thermal inertia, the reheating phase - on building's thermal inertia and power of the heating system and neither of these have any effect on the setback period phase (Figs 7 and 8). 


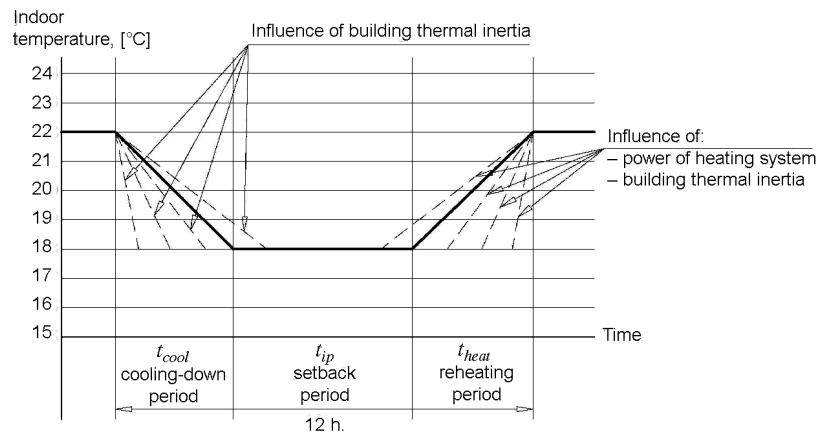

Fig. 7. Phases of intermitted heating, during the $12 \mathrm{~h}$ of daily temperature reduced period

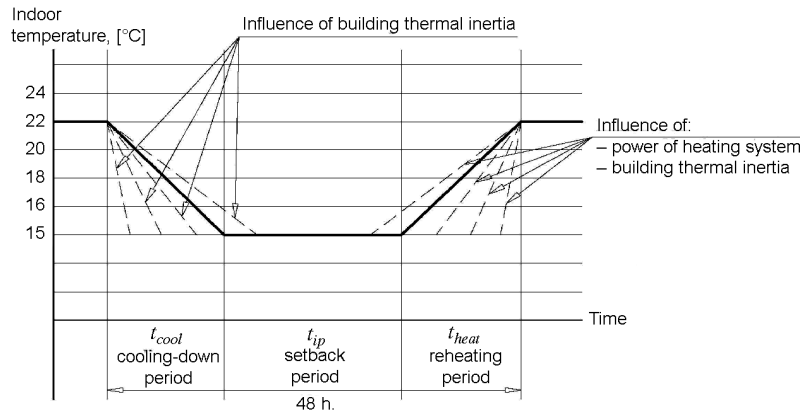

Fig. 8. Phases of intermitted heating, during the $48 \mathrm{~h}$ of weekend temperature reduced period

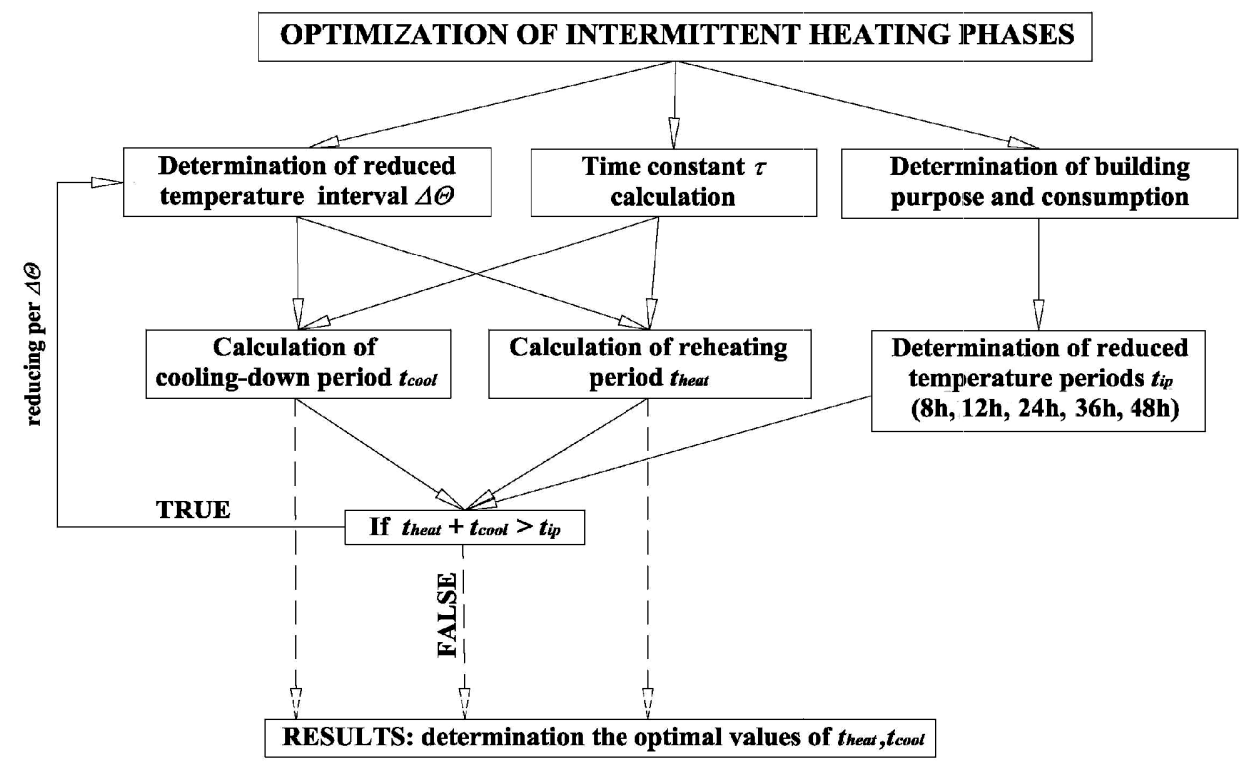

Fig. 9. Optimization algorithm of intermittent heating phases

Intermittent central heating system which operates according to a present intermittent scheduled that is determined based on outdoor air temperature (Kim et al. 2010). The idea of intermittent heating phases optimization is to minimize the setback period $t_{i p}$, leaving the cooling-down phase $t_{\text {cool }}$ and the reheating phase $t_{\text {heat }}$ which use the thermal energy. This method optimizes only the phases of intermittent heating and does not change the level of building's thermal inertia or use of additional power of heating system. The algorithm in Fig. 9 illustrates the sequence of optimization stages.

\subsection{Thermal energy saving by using intermittent heating with additional power of heating system}

After the building cools down, room temperature has to be restored in as short time as possible. Economical effect is achieved through intermittent heating of the building by use of additional power of heating system.

Reduced temperature periods are applied 5 times per week for 12 hours period at night and 48 hours at week- end. The price of thermal energy is set at $0.30 \mathrm{LTL} / \mathrm{kWh}$. Energy savings are calculated for an average heating season period in Kaunas city - 192 days, under "average" outdoor temperature conditions (see 2.1).

The price of heating system is specified according to the following parameters: heat production (boiler, heating unit, heat exchanger), piping of the heating system (pipes, heat insulation, manifolds, fittings) and heating units (radiators). The costs were calculated by a special program "SES2004" and following the price database of March 2009.

The payback is received after the first heating season (Fig. 10). The red curves depict the cost of installing additional power to the heating system: continuous line without interest, dotted line - for a one-year loan with $12 \%$ annual interest rate. The points of crossing of the red curves with the other lines are the points of payback, whereas the values above the red curves indicate economical benefit (Figs 10 and 11). 


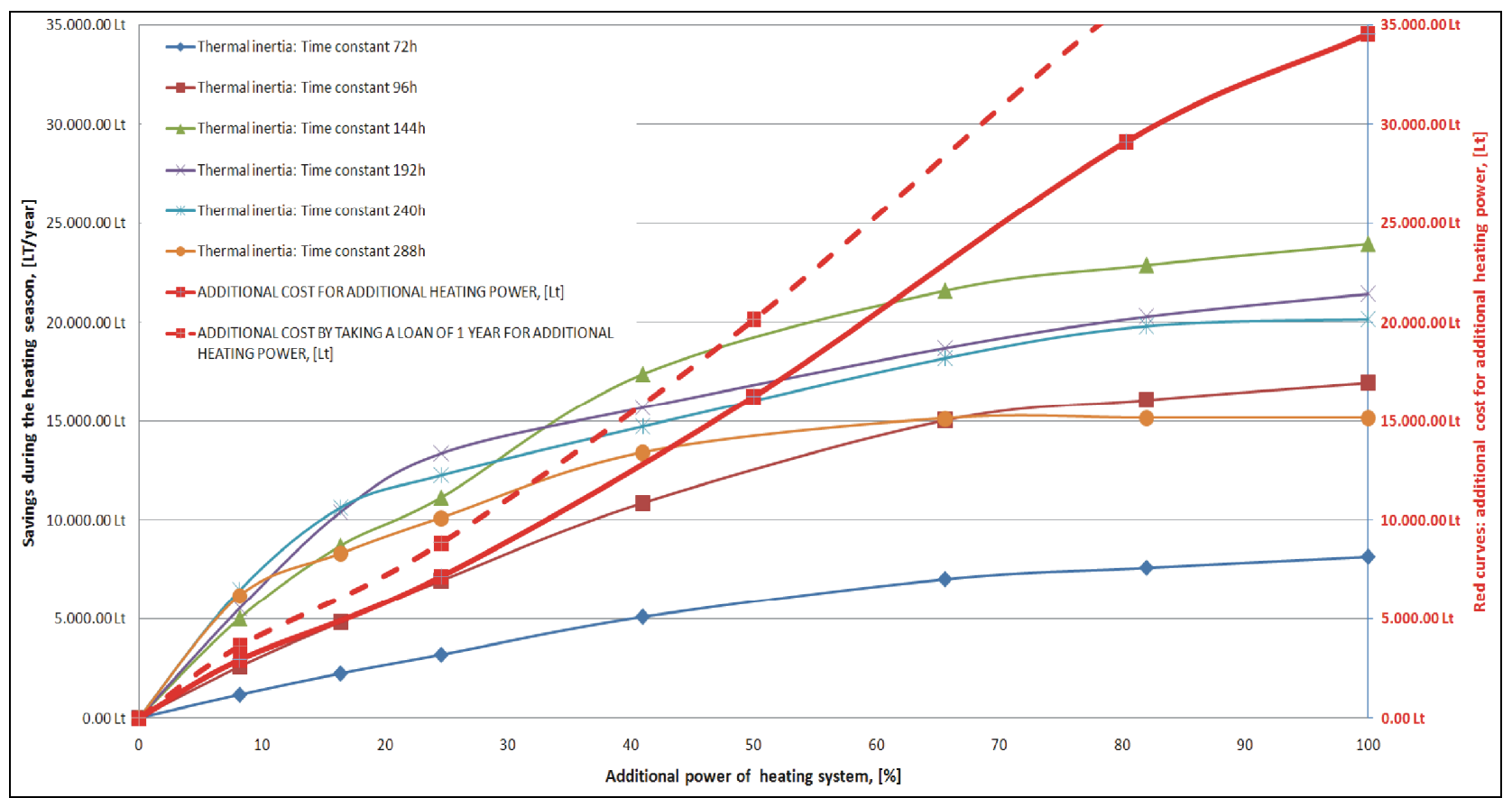

Fig. 10. Savings of thermal energy during the heating season by use of intermittent heating and additional power of heating system in various cases of thermal time constant

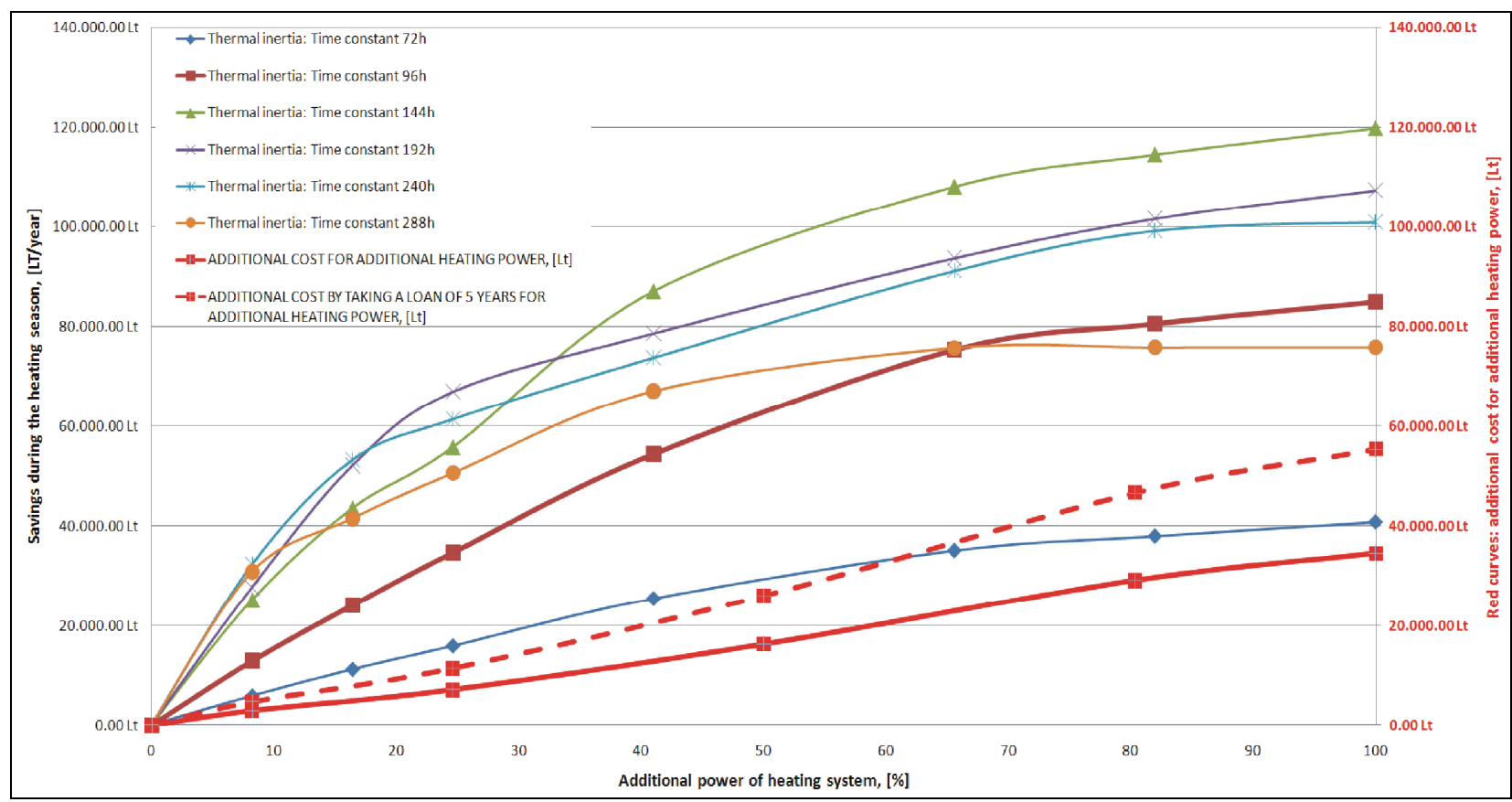

Fig. 11. Savings of thermal energy during 5 years (heating seasons) by use of intermittent heating and additional power of heating system in various cases of thermal time constant

\section{Conclusions and recommendations}

- Intermittent heating, probably it's the most simplest way to reduce thermal energy consumption.

- In North countries dominating buildings with medium values of time constant ( $\sim 96 \mathrm{~h}-144 \mathrm{~h})$. Under the "extreme" outdoor temperature conditions, these building's temperature regeneration from $0{ }^{\circ} \mathrm{C}$ to $22{ }^{\circ} \mathrm{C}$ time is about $24-48 \mathrm{~h}$.

- Under "average" outdoor temperature conditions (see 2.1) the use of intermittent heating and addi- tional power of heating system, the economical benefit is gained after the first heating season. The most efficient case is considered $50 \%$ of additional power of the heating system and $144 \mathrm{~h}$ time constant value of building, when $12 \mathrm{~h}$ at night and $48 \mathrm{~h}$ at weekend temperature reduction periods are applied for office buildings.

- The buildings with higher thermal inertia than $144 \mathrm{~h}$ require longer $(>48 \mathrm{~h})$ temperature reduction periods in order to reduce payback time. 
- The research has shown that for low-mass buildings $(<72 \mathrm{~h})$ the introduction of additional power of the heating system when intermittent heating is applied, larger additional power value than $60 \%$ does not provide economical benefit, taking into account the interest of a loan after 5 years.

- The cooling-down curves of buildings showed (Fig. 4), that indoor cooling-down time (from $22{ }^{\circ} \mathrm{C}$ to $0{ }^{\circ} \mathrm{C}$ ) varies from $25 \mathrm{~h}$ to $200 \mathrm{~h}$ under "extreme" outdoor temperature conditions in various cases of thermal inertia.

\section{References}

Corgnati, S. P.; Kindinis, A.; Perino, M. 2009. Thermal mass activation be means of night cooling: comparison on different techniques and strategies, in $5^{\text {th }}$ International Workshop on Energy and Environment of Residential Buildings $/ 3^{\text {th }}$ International Conference on Built Environment and Public Health: Selected papers, vol. I and II. Ed. by Q. Zhang, M. Leung. May 29-31, 2009, Guilin, China. Hunan: Hunan University, 685-693.

EN ISO 13790. 2004. Thermal performance of buildings Calculation of energy use for heating. Brussel.

EN 832. 1998. Thermal performance of buildings - Calculation of energy use for heating - Residential buildings. Brussel.

Ginevičius, R.; Podvezko, V.; Raslanas, S. 2008. Evaluating the alternative solutions of wall insulation by multicriteria methods, Journal of Civil Engineering and Management 14(4): 217-226. doi:10.3846/1392-3730.2008.14.20

Holopainen, R.; Hekkanen, M. 2008. Energy renovation saving potentials of typical Finnish buildings, in Proceedings of the $8^{\text {th }}$ Symposium on Building Physics in the Nordic countries: Selected papers, vol. 3. Ed. by C. Rode. June 16-18, 2008, Copenhagen, Denmark. Copenhagen: Danish Society of Engineers, 1119-1125.

Hagentoft, C. E. 2001. Introduction to building physics. Lund: Studentlitteratur.

Incropera, F. P.; DeWitt, D. P. 1985. Introduction to heat transfer. New York: John Wiley\&Sons.

Juodvalkis, J. 2008. Nestacionarieji šilumos mainai pastatuose [Unsteady heat exchanges in buildings]. Kaunas: Technologija. ISBN 978-9955-9750-3-8.

Juodvalkis, J.; Blaževičius, E.; Vipartas, R. A. 2000. Analysis of an unsteady heat exchange balance in buildings, Journal of Civil Engineering and Management 6(1): 32-38.

Kim, M. S.; Kim, Y.; Chung, K. S. 2010. Improvement of intermittent central heating system of university building, Energy and Buildings 42(1): 83-89. doi:10.1016/j.enbuild.2009.07.014

Karbauskaitè, J.; Stankevičius, V.; Burlingis, A.; Morkvenas, R. 2008. The assessment of freezing risk in apartment buildings after the supply break, in Proceedings of the $8^{\text {th }}$ Symposium on Building Physics in the Nordic Countries: Selected papers, vol. 3. Ed. by C. Rode. June 16-18, 2008, Copenhagen, Denmark. Copenhagen: Danish society of engineers, 1341-1347.

Kalema, T.; Pylsy, P. 2008. Accuracy of the calculation of heating and cooling energy needs in Nordic conditions, in Proceedings of the $8^{\text {th }}$ Symposium on Building Physics in the Nordic Countries: Selected papers, vol. 3. Ed. by C. Rode. June 16-18, 2008, Copenhagen, Denmark. Copenhagen: Danish society of engineers, 535-542.
Olsen, L. 2008. Heat capacity in relation to the Danish building regulation, in Proceedings of the $8^{\text {th }}$ Symposium on Building Physics in the Nordic Countries: Selected papers, vol. 3. Ed. by C. Rode. June 16-18, 2008, Copenhagen, Denmark. Copenhagen: Danish society of engineers, 1349-1356.

RSN 156-94. 1995. Statybine klimatologija [Climatology of buildings]. Vilnius.

Stankevičius, V.; Karbauskaite, J.; Burlingis, A. 2007. Gyvenamujų daugiabučių pastatų avarinio atvėsimo analizès rezultatai [The results of emergency cooling-down investigation of apartment buildings], Šilumine technika 1(30): 6-9.

Stankevičius, V.; Barkauskas, V. 2000. Pastatu atitvaru šilumine fizika [Building physics]. Kaunas: Technologija. ISBN 9986-13-740-3

Valančius, K. 2006. Pastato aktyviosios šiluminès talpos itaka patalpu mikroklimatui bei energijos poreikiams [Influence of active heat capacity on microclimate and energy demand of a building]. Doctoral dissertation. Vilnius Gediminas Technical University. Vilnius: Technika.

STR 2.09.04. 2002. Pastato šildymo sistemos galia. Energijos sqnaudos šildymui [Power of the building heating system. Energy consumption for the heating]. Vilnius: Ministry of Environment of the Republic of Lithuania.

STR 2.09.04. 2008. Pastato šildymo sistemos galia. Šilumos poreikis šildymui [Power of the building heating system. Energy demand of the heating]. Vilnius: Ministry of Environment of the Republic of Lithuania.

STR 2.05.01. 2005. Pastatu atitvaru šilumine technika [Thermal technique of building envelopes]. Vilnius: Ministry of Environment of the Republic of Lithuania.

Šadauskienè, J.; Buska, A.; Burlingis, A.; Bliūdžius, R.; Gailius, A. 2009. The effect of vertical air gaps to thermal transmittance of horizontal thermal insulating layer, Journal of Civil Engineering and Management 15(3): 309315. doi:10.3846/1392-3730.2009.15.309-315

Šeduikytė, L.; Paukštys, V. 2008. Evaluation of indoor environment conditions in offices located in buildings with large glazed areas, Journal of Civil Engineering and Management 14(1): 39-44.

doi:10.3846/1392-3730.2008.14.39-44

Valančius, K.; Skrinska, A. K.; Paulauskaite, S. 2006. Investigation of unsteady heat transfer process in an one-cell building, Journal of Civil Engineering and Management 12(1): 97-101.

Valančius, K.; Sasnauskaite, V. 2008. An influence of the control of heating system to the design heat load and demand of a building, in The 7th International Conference "Environmental engineering": May 22-23, 2008, Vilnius, Lithuania. Vilnius: Technika, 882-885.

Valančius, K.; Paulauskaite, S. 2004. Energy conservation law appliance for intermittent heating analysis, in The $6^{\text {th }} \mathrm{In}$ ternational Conference on Energy for Buildings: Selected papers, Ed. By E. Abel, V. Martinaitis, B. Todorovic. Oct 07-08, 2004, Vilnius, Lithuania. Vilnius: Technika, 540-547.

Valančius, K.; Skrinska, A. 2003. An intermittent heating influence to the building reheating time and design heat load, in The $4^{\text {th }}$ Baltic Heat Transfer Conference: Selected papers, Ed. by B. Sunden, J. Vilemas. Aug 25-27, 2003, Kaunas, Lithuania. New York: Begell House, 277-282.

Zebergs, V.; Zeltins, N.; Davis, A.; Vrublevski, V. 2009 Methodological problems of evaluation of the building enve- 
lopes depending on their thermal inertia and balance temperature, in $5^{\text {th }}$ International Workshop on Energy and Environment of Residential Buildings / $3^{\text {th }}$ International Conference on Built Environment and Public Health: Selected papers, vol. I and II. Ed. By Q. Zhang, M. Leung.
May 29-31, 2009, Guilin, China. Hunan: Hunan University, $1385-1394$.

Фокин, К. Ф. 2006. Строительная теплотехника ограждаюших частей зданий [Phokin, K. Ph. Thermal physics of building partitions]. Москва: АВОК (in Russian).

\section{PASTATO ŠILDYMO SISTEMOS PAPILDOMO GALINGUMO ĮTAKA TAIKANT PROTARPINI ŠILDYMĄ}

\section{Pupeikis, A. Burlingis, V. Stankevičius}

\section{$\mathrm{S}$ a $\mathrm{n} \mathrm{t} \mathrm{r} \mathrm{a} \mathrm{u} \mathrm{k} \mathrm{a}$}

Šildant pastata, esant papildomai šiluminei galiai, galima sumažinti sunaudojamos šiluminès energijos. Nustatyta, kad papildomos šiluminès galios $(+50 \%)$ sąnaudos, siekiant pagreitinti temperatūros padidinimą vidutinio masyvumo $(\tau=$ $144 \mathrm{~h}$ ) pastatų patalpose ir taikant protarpini šildymą ( $12 \mathrm{~h}$ darbo dienomis ir $48 \mathrm{~h}$ savaitgaliais), atsiperka po vienerių metų. Projektuojant reikia atsižvelgti i pastato paskirti, masyvumą ir šildymo sistemos galia, siekiant sutaupyti šiluminès energijos bei gauti ekonominę nauda, taikant protarpinį šildymą. Tyrimai parodè, kad ịvairaus masyvumo pastatams turi būti taikomi atitinkami protarpinio šildymo periodai.

Reikšminiai žodžiai: pastato šildymo sistema, protarpinis šildymas, pastato vėsimas, pastato šilimas, išorès oro temperatūra, pastato modeliavimas, šiluminės energijos suvartojimas, sutaupyta šiluminé energija.

Darius PUPEIKIS. PhD student of Civil Engineering, Researcher at the Laboratory of Thermal Building Physics of the Institute of Architecture and Construction, KTU. Research interests: unsteady heat transfer, thermal energy balance of buildings.

Arūnas BURLINGIS. Doctor, Senior Researcher at the Laboratory of Thermal Building Physics at the Institute of Architecture and Construction, KTU. Research interests: thermal processes in building, thermal and hydro properties of building materials and elements.

Vytautas STANKEVIČIUS. Doctor Habil., Full Professor, Chief Researcher at the Laboratory of Thermal Building Physics of the Institute of Architecture and Construction, KTU. Research interests: heat transfer, technical properties of thermal insulations products. 